Research paper

\title{
Antitumor and anti-Mycobacterium tuberculosis agents based on cationic ruthenium complexes with amino acids
}

\author{
Edjane R. dos Santos ${ }^{a, *}$, Rodrigo S. Corrêa ${ }^{b}$, Lucas V. Pozzi ${ }^{a}$, Angelica E. Graminha ${ }^{\text {a }}$, \\ Heloisa S. Selistre-de-Araújo ${ }^{c}$, Fernando R. Pavan ${ }^{\mathrm{d}}$, Alzir A. Batista ${ }^{\mathrm{a}, *}$ \\ a Departamento de Química, Universidade Federal de São Carlos, C.P. 676, CEP 13565-905 São Carlos, SP, Brazil \\ ${ }^{\mathrm{b}}$ Departamento de Química, ICEB, Universidade Federal de Ouro Preto, CEP 35400-000 Ouro Preto, MG, Brazil \\ 'Departamento de Ciências Fisiológicas, Universidade Federal de São Carlos, C.P. 676, CEP 13565-905 São Carlos, SP, Brazil \\ ${ }^{\mathrm{d}}$ Departamento de Ciências Biológicas, Faculdade de Ciências Farmacêuticas, UNESP, CEP 14800-900 Araraquara, SP, Brazil
}

\section{A R T I C L E I N F O}

\section{Article history:}

Received 25 March 2017

Accepted 6 April 2017

Available online 8 April 2017

Keywords:

Ruthenium complexes

Amino acid

Diastereoisomers

Cytotoxicity

Anti-Mycobacterial tuberculosis

\begin{abstract}
A B S T R A C T
Six new complexes of $\mathrm{Ru}(\mathrm{II}) /$ phenanthroline/1,4-bis(diphenylphosphino)butane containing amino acids (Glycine, L-Alanine, L-Valine, L-Tyrosine, L-Methionine or L-Tryptophan) were synthesized and characterized by IR, ${ }^{31} \mathrm{P}\left\{{ }^{1} \mathrm{H}\right\},{ }^{13} \mathrm{C}$ and ${ }^{1} \mathrm{H}$ NMR spectroscopies and cyclic voltammetry experiments. These data suggest the presence of diastereoisomers, except for the complex with glycine, amino acid that does not exhibit chiral carbon. The compounds are active against the MDA-MB-231 tumor cells and against Mycobacterium tuberculosis. The cationic ruthenium complexes with amino acids, reported here, show similar cytotoxicity against the MDA-MB-231 tumor cells. When compared with analogs complexes containing 2,2'-bipyridine as ligands, instead of 1,10-phenatroline, the new complexes studied here are, in general, roughly twice more active than the $2,2^{\prime}$-bipyridine ones and their $\mathrm{IC}_{50}$ values comparable with the cisplatin. In addition, low MICs values were obtained against Mycobacterium tuberculosis compared with the reference drugs, cycloserine and ethambutol.
\end{abstract}

(c) 2017 Elsevier B.V. All rights reserved.

\section{Introduction}

Transition metal complexes represent a very important class of promising chemotherapeutics. Many researchers have proposed a large number of metal complexes as potential anticancer agents, and/or with antibacterial properties [1-21]. Among then, ruthenium compounds have been widely investigated, showing interesting biological effects [22-26].

In addition, metal complexes with amino acids have been explored due to their notable potential role in cancer therapy [1,17-20,27-30], in which octahedral complexes containing amino acids tend to form diastereoisomers due to their chiral carbon, forming complexes with $\Delta$ and $\Lambda$ configurations around the metal [31-37].

Recently, our research group has published interesting biological results of ruthenium/biphosphine complexes exhibiting good cytotoxicity against tumor cells and/or good activity anti-Mycobacterial tuberculosis $[1,2,15,17,19-20,38,39]$. Thus, continuing the search for antitumor agents with better cytotoxicity against tumor

\footnotetext{
* Corresponding authors.

E-mail addresses: edjanemrocha@gmail.com (E.R. dos Santos), daab@ufscar.br (A.A. Batista).
}

cells and/or also with good anti-Mycobacterial tuberculosis properties, we present here the synthesis, characterization and investigation of a series of ruthenium complexes with amino acids. Also, the cytotoxic activity against the MDA-MB-231 tumor cells and against Mycobacterium tuberculosis were carried out.

\section{Experimental}

\subsection{Materials and measurements}

All reactions were carried out under an argon atmosphere using standard Schlenk techniques. Reagent grade solvents were appropriately dried and distilled before use. All chemicals used were of reagent grade or of comparable purity. All chemicals were purchased from Aldrich or Fluka and were used as received. The precursor cis- $\left[\mathrm{RuCl}_{2}(\mathrm{dppb})(\right.$ phen)] was prepared using published procedures [19], where dppb means 1,4-bis(diphenylphosphino) butane and phen is phenanthroline.

The IR spectra of the complexes were recorded on a FT-IR Bomem-Michelson 102 spectrometer in the $4000-200 \mathrm{~cm}^{-1}$ region, using solid samples pressed in CsI pellets. All nuclear magnetic resonance (NMR) experiments were recorded on a BRUKER 
spectrometer, in a BBO $5 \mathrm{~mm}$ probe at room temperature, observing ${ }^{1} \mathrm{H}$ at $400.13 \mathrm{MHz}$ using deuterated chloroform $\left(\mathrm{CDCl}_{3}\right)$ as solvent and ${ }^{31} \mathrm{P}\left\{{ }^{1} \mathrm{H}\right\}$ at $161.98 \mathrm{MHz}$ in $\mathrm{CH}_{2} \mathrm{Cl}_{2}$ using a capillary of $\mathrm{D}_{2} \mathrm{O}$ to get the lock. In the ${ }^{31} \mathrm{P}\left\{{ }^{1} \mathrm{H}\right\}$ experiments chemical shifts are with respect $85 \% \mathrm{H}_{3} \mathrm{PO}_{4}$ signal as external reference and ${ }^{1} \mathrm{H}$ and ${ }^{13} \mathrm{C}\left\{{ }^{1} \mathrm{H}\right\}$ experiments were calibrated by TMS signal as internal references. The molar conductivity measurements $\left(\Lambda_{\mathrm{m}}\right)$ were taken in dichloromethane at $25^{\circ} \mathrm{C}$, using concentrations of $1.0 \times 10^{-3} \mathrm{M}$ for the complexes. Cyclic voltammetry (CV) experiments were carried out at room temperature in dichloromethane $\left(\mathrm{CH}_{2} \mathrm{Cl}_{2}\right)$ containing $0.100 \mathrm{~mol} \mathrm{~L}^{-1} \mathrm{Bu}_{4} \mathrm{NClO}_{4}$ (TBAP) (FlukaPurum) using a BAS-100B/ W Bioanalytical Systems Instrument. The working and auxiliary electrodes were stationary Pt foils; the reference electrode was of $\mathrm{Ag} / \mathrm{AgCl}$, in a Luggin capillary probe. Ultraviolet-visible (UV-vis) spectra were recorded on a HP 8452A diode array spectrophotometer. CHNS elemental analyses were carried out on EA 1108 of the FISONS.

\subsection{Synthesis}

\subsubsection{Synthesis of complexes $[R u(A A-H)(d p p b)($ phen $)] P F_{6}$,}

$A A=$ glycine; L-Alanine; L-Valine; L-Tyrosine; L-Methionine; $L$ Tryptophan

The synthetic procedure used in this work was similar to that used in the literature $[1,20]$. As an example, $0.011 \mathrm{~g}(0.15 \mathrm{mmol})$ of glycine was added to a Schlenk flask, and was dissolved in $50 \mathrm{~mL}$ of methanol previously deoxygenated. Once the glycine was fully solubilized, $0.08 \mathrm{~g}(0.10 \mathrm{mmol})$ of the precursor, cis$\left[\mathrm{RuCl}_{2}(\mathrm{dppb})(\right.$ phen $\left.)\right]$, was added to the flask followed by an addition of $0.025 \mathrm{~g}(0.16 \mathrm{mmol})$ of $\mathrm{NH}_{4} \mathrm{PF}_{6}$. The mixture was allowed to reflux for $48 \mathrm{~h}$. After completing the reaction, the solution volume was reduced to about $1.0 \mathrm{~mL}$, and deoxygenated diethyl ether was added promoting the precipitation of a solid, which was collected on a fritted funnel, washed with water and ethyl ether, and dried under vacuum. Yield $0.086 \mathrm{~g}(90 \%)$. This synthetic route was used for the other amino acid complexes synthesized in this work. The yields for the other complexes were also in the order of $90 \%$. The characterization of the synthesized complexes are described above:

2.2.1.1. $[\mathrm{Ru}(\mathrm{Gly}-\mathrm{H})(\mathrm{dppb})($ phen $)] P F_{6}$. UV-vis $\left(\mathrm{CH}_{2} \mathrm{Cl}_{2}\right) \lambda / \mathrm{nm} 266$, 374; IR (CsI) $v / \mathrm{cm}^{-1} 3439,1616,1385,852,557,509,420 ;{ }^{1} \mathrm{H}$ NMR $\left(400.21 \mathrm{MHz}, \mathrm{CDCl}_{3}\right) \delta 1.37\left(\mathrm{~m}, 1 \mathrm{H}, \mathrm{CH}_{2}\right), 2.20-2.00(\mathrm{~m}, 2 \mathrm{H}$, $\left.\mathrm{CH}_{2}\right), 2.54-2.25\left(\mathrm{~m}, 3 \mathrm{H}, \mathrm{CH}_{2}\right), 2.64\left(\mathrm{~m}, 1 \mathrm{H}, \mathrm{CH}_{2}\right), 3.52(\mathrm{~m}, 1 \mathrm{H}$, $\mathrm{CH}_{2}$ ), 3.57 (t, 4H, Gly), 5.99 (t, 2H, J 8.8, Ph), 6.65 (t, $1 \mathrm{H}, J 6.8$, phen), $7.12(\mathrm{dt}, 1 \mathrm{H}, J 6.8,1.6$, phen), 7.45-7.35 (m, $4 \mathrm{H}, \mathrm{Ph}), 7.66-7.48(\mathrm{~m}$, $5 \mathrm{H}, \mathrm{Ph}), 7.82-7.72(\mathrm{~m}, 3 \mathrm{H}, \mathrm{Ph}), 7.87(\mathrm{t}, 2 \mathrm{H}, J$ 8.0, Ph), 8.05-7.96 (m, $1 \mathrm{H}$, phen; $2 \mathrm{H}, \mathrm{Ph}), 8.14$ (d, $1 \mathrm{H}, J$ 9.2, phen), $8.52-8.49$ (m, $1 \mathrm{H}$, phen; $2 \mathrm{H}, \mathrm{Ph}), 8.74$ (d, $1 \mathrm{H}, J$ 8.4, phen), 9.20 (d, 1H, J 5.2, phen), 9.39 (m, $1 \mathrm{H}$, phen); ${ }^{13} \mathrm{C}$ NMR $\left(100.05 \mathrm{MHz}, \mathrm{CDCl}_{3}\right) \delta 52.4,183.6 ;{ }^{31} \mathrm{P}\left\{{ }^{1} \mathrm{H}\right\}$ NMR (162 MHz, $\left.\mathrm{CH}_{2} \mathrm{Cl}_{2} / \mathrm{D}_{2} \mathrm{O}\right) \delta\left(\mathrm{d}, 47.2\right.$ and 40.7, $\left.{ }^{2} J_{P P} 33.4\right) ; \Lambda_{\mathrm{M}} /$ $\left(\Omega^{-1} \mathrm{~cm}^{2} \mathrm{~mol}^{-1}\right)$ 30.03; calcd for $\mathrm{C}_{42} \mathrm{H}_{40} \mathrm{~F}_{6} \mathrm{~N}_{3} \mathrm{O}_{2} \mathrm{P} 3 \mathrm{Ru}$ : C, 54.43; $\mathrm{H}$, 4.35 ; N, 4.53\%; found: C, 54.43; H, 4.49; N, $4.51 \%$.

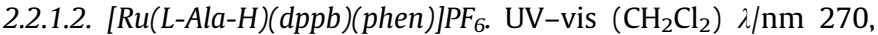
408; IR (CSI) $v / \mathrm{cm}^{-1}$ 3439, 1622, 1385, 854, 557, 509, 420; ${ }^{1} \mathrm{H}$ NMR $\left(400.21 \mathrm{MHz}, \mathrm{CDCl}_{3}\right) \delta 1.37\left(\mathrm{~m}, 1 \mathrm{H}, \mathrm{CH}_{2}\right), 1.48\left(\mathrm{~s}, 3 \mathrm{H}, \mathrm{CH}_{3}\right.$, Ala ), 2.20-2.00 (m, $\left.2 \mathrm{H}, \mathrm{CH}_{2}\right), 2.54-2.25\left(\mathrm{~m}, 3 \mathrm{H}, \mathrm{CH}_{2}\right), 2.64(\mathrm{~m}$, $\left.1 \mathrm{H}, \mathrm{CH}_{2}\right), 3.52\left(\mathrm{~m}, 1 \mathrm{H}, \mathrm{CH}_{2}\right), 3.79(\mathrm{t}, 3 \mathrm{H}, \mathrm{Ala}), 5.99(\mathrm{t}, 2 \mathrm{H}, J$ 8.8, $\mathrm{Ph}), 6.65(\mathrm{t}, 1 \mathrm{H}, J 6.8$, phen), $7.12(\mathrm{dt}, 1 \mathrm{H}, J 6.8,1.6$, phen $), 7.45-$ $7.35(\mathrm{~m}, 4 \mathrm{H}, \mathrm{Ph}), 7.66-7.48(\mathrm{~m}, 5 \mathrm{H}, \mathrm{Ph}), 7.82-7.72(\mathrm{~m}, 3 \mathrm{H}, \mathrm{Ph})$, $7.87(\mathrm{t}, 2 \mathrm{H}, J$ 8.0, Ph), 8.05-7.96 (m, 1H, phen; $2 \mathrm{H}, \mathrm{Ph}), 8.14(\mathrm{~d}$, $1 \mathrm{H}, J$ 9.2, phen), $8.52-8.49(\mathrm{~m}, 1 \mathrm{H}$, phen; $2 \mathrm{H}, \mathrm{Ph}), 8.74$ (d, $1 \mathrm{H}, J$ 8.4, phen), 9.20 (d, $1 \mathrm{H}, J 5.2$, phen), $9.39\left(\mathrm{~m}, 1 \mathrm{H}\right.$, phen); ${ }^{13} \mathrm{C}$ NMR $\left(100.05 \mathrm{MHz}, \mathrm{CDCl}_{3}\right) \delta 19.2,48.3,185.3$ and $182.9 ;{ }^{31} \mathrm{P}\left\{{ }^{1} \mathrm{H}\right\} \mathrm{NMR}$ $\left(162 \mathrm{MHz}, \mathrm{CH}_{2} \mathrm{Cl}_{2} / \mathrm{D}_{2} \mathrm{O}\right) \delta\left(\mathrm{d}, 46.9\right.$ and 38.4, $\left.{ }^{2} J_{P P} 33.2\right)$ and $(\mathrm{d}, 44.7$ and 38.1, $\left.{ }^{2} J_{P P} 33.2\right) ; \Lambda_{\mathrm{M}} /\left(\Omega^{-1} \mathrm{~cm}^{2} \mathrm{~mol}^{-1}\right) 27.29$; calcd for $\mathrm{C}_{43} \mathrm{H}_{42} \mathrm{~F}_{6}$ $\mathrm{N}_{3} \mathrm{O}_{2} \mathrm{P}_{3} \mathrm{Ru}$ : C, 54.90; H, 4.50; N, 4.47\%; found: C, 54.81; H, 4.46; N, $4.13 \%$.

2.2.1.3. $[\mathrm{Ru}(\mathrm{L}-\mathrm{Val}-\mathrm{H})(\mathrm{dppb})($ phen $)] P F_{6}$. UV-vis $\left(\mathrm{CH}_{2} \mathrm{Cl}_{2}\right) \lambda / \mathrm{nm} 270$, 408; IR (CsI) $v / \mathrm{cm}^{-1}$ 3443, 1624, 1385, 847, 557, 509, 420; ${ }^{1} \mathrm{H}$ NMR $\left(400.21 \mathrm{MHz}, \mathrm{CDCl}_{3}\right) \delta 1.37\left(\mathrm{~m}, 1 \mathrm{H}, \mathrm{CH}_{2}\right), 1.7\left(\mathrm{t}, 6 \mathrm{H}, \mathrm{CH}_{3}\right.$, Val), 2.20-2.00 (m, $\left.2 \mathrm{H}, \mathrm{CH}_{2}\right), 2.3\left(\mathrm{t}, 1 \mathrm{H}, \mathrm{CH}_{3}, \mathrm{Val}\right), 2.54-2.25(\mathrm{~m}$, $\left.3 \mathrm{H}, \mathrm{CH}_{2}\right), 2.64\left(\mathrm{~m}, 1 \mathrm{H}, \mathrm{CH}_{2}\right), 3.52\left(\mathrm{~m}, 1 \mathrm{H}, \mathrm{CH}_{2}\right), 3.6(\mathrm{t}, 3 \mathrm{H}, \mathrm{Val})$, 5.99 (t, 2H, J 8.8, Ph), 6.65 (t, 1H, J 6.8, phen), 7.12 (dt, 1H, J 6.8, 1.6, phen), 7.45-7.35 (m, $4 \mathrm{H}, \mathrm{Ph}), 7.66-7.48(\mathrm{~m}, 5 \mathrm{H}, \mathrm{Ph}), 7.82-$ $7.72(\mathrm{~m}, 3 \mathrm{H}, \mathrm{Ph}), 7.87(\mathrm{t}, 2 \mathrm{H}, J$ 8.0, Ph), 8.05-7.96 (m, $1 \mathrm{H}$, phen; $2 \mathrm{H}, \mathrm{Ph}$ ), 8.14 (d, $1 \mathrm{H}, J$ 9.2, phen), 8.52-8.49 (m, $1 \mathrm{H}$, phen; $2 \mathrm{H}$, $\mathrm{Ph}$ ), 8.74 (d, $1 \mathrm{H}, J 8.4 \mathrm{~Hz}$; phen), 9.20 (d, 1H, J $5.2 \mathrm{~Hz}$; phen), 9.39 (m, $1 \mathrm{H}$, phen); ${ }^{13} \mathrm{C}$ NMR $\left(100.05 \mathrm{MHz}, \mathrm{CDCl}_{3}\right) \delta 30.0,58.4,182.2$ and 180.9; ${ }^{31} \mathrm{P}\left\{{ }^{1} \mathrm{H}\right\}$ NMR (162 MHz, $\left.\mathrm{CH}_{2} \mathrm{Cl}_{2} / \mathrm{D}_{2} \mathrm{O}\right) \delta(\mathrm{d}, 47.0$ and 38.9, $\left.{ }^{2} J_{P P} 33.0\right)$ and (d, 42.9 and 38.5, $\left.{ }^{2} J_{P P} 32.8\right) ; \Lambda_{\mathrm{M}} /\left(\Omega^{-1} \mathrm{~cm}^{2}\right.$ mol $^{-1}$ ) 34.17; calcd for $\mathrm{C}_{45} \mathrm{H}_{46} \mathrm{~F}_{6} \mathrm{~N}_{3} \mathrm{O}_{2} \mathrm{P}_{3} \mathrm{Ru}$ : C, 55.79; $\mathrm{H}, 4.79$; N, 4.34\%; found: C, 55.42; $\mathrm{H}, 4.80 ; \mathrm{N}, 4.26 \%$.

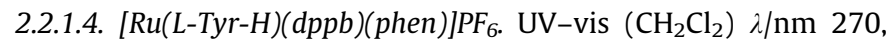
408; IR (CsI) $v / \mathrm{cm}^{-1} 3443,1616,1385,860,557,509,420 ;{ }^{31} \mathrm{P}$ $\left\{{ }^{1} \mathrm{H}\right\}$ NMR $\left(162 \mathrm{MHz}, \mathrm{CH}_{2} \mathrm{Cl}_{2} / \mathrm{D}_{2} \mathrm{O}\right) \delta\left(\mathrm{d}, 47.8\right.$ and 38.9, $\left.{ }^{2} J_{P P} 34.4\right)$ and (d, 42.9 and 38.1, $\left.{ }^{2} J_{P P} 32.9\right) ; \Lambda_{\mathrm{M}} /\left(\Omega^{-1} \mathrm{~cm}^{2} \mathrm{~mol}^{-1}\right)$ 30.99; calcd for $\mathrm{C}_{49} \mathrm{H}_{46} \mathrm{~F}_{6} \mathrm{~N}_{3} \mathrm{O}_{3} \mathrm{P}_{3} \mathrm{Ru}$ : C, 56.98; $\mathrm{H}, 4.49 ; \mathrm{N}, 4.07 \%$;, $57.00 ; \mathrm{H}$, $4.48 ; \mathrm{N}, 4.03 \%$.

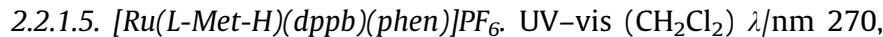
406; IR (CsI) $v / \mathrm{cm}^{-1} 3441,1624,1385,843,557,509,420 ;{ }^{1} \mathrm{H}$ NMR (400.21 MHz, $\left.\mathrm{CDCl}_{3}\right) \delta 1.82\left(\mathrm{~m}, 4 \mathrm{H}, \mathrm{dppb}, \mathrm{CH}_{2}\left(\mathrm{CH}_{2}\right)_{2} \mathrm{CH}_{2}\right)$, 2.0 (s, 3H, $\left.\mathrm{CH}_{3}, \mathrm{Met}\right), 2.3$ (t, 4H, Met), 2.77 (m, 4H, dppb, $\mathrm{CH}_{2}(-$ $\left.\mathrm{CH}_{2}\right)_{2}\left(\mathrm{CH}_{2}\right), 3.8$ (t, 3H, Met), 5.99 (t, 2H, J 8.8; Ph), $6.65(\mathrm{t}, 1 \mathrm{H}, J$ 6.8, phen), $7.12(\mathrm{dt}, 1 \mathrm{H}, J 6.8,1.6$, phen); 7.45-7.35 (m, $4 \mathrm{H}, \mathrm{Ph})$; 7.66-7.48 (m, 5H, Ph); 7.82-7.72 (m, 3H, Ph), $7.87(\mathrm{t}, 2 \mathrm{H}, J 8.0$ $\mathrm{Ph}), 8.05-7.96(\mathrm{~m}, 1 \mathrm{H}$, phen; $2 \mathrm{H}, \mathrm{Ph}), 8.14(\mathrm{~d}, 1 \mathrm{H}, J$ 9.2, phen), 8.52-8.49 (m, $1 \mathrm{H}$, phen; $2 \mathrm{H}, \mathrm{Ph}), 8.74(\mathrm{~d}, 1 \mathrm{H}, J$ 8.4, phen), $9.20(\mathrm{~d}$, $1 \mathrm{H}, J$ 5.2, phen), 9.39 (m, $1 \mathrm{H}$, phen); ${ }^{31} \mathrm{P}\left\{{ }^{1} \mathrm{H}\right\}$ NMR (162 MHz, $\mathrm{CH}_{2^{-}}$ $\left.\mathrm{Cl}_{2} / \mathrm{D}_{2} \mathrm{O}\right) \delta\left(\mathrm{d}, 48.0\right.$ and $\left.40.1,{ }^{2} J_{P P} 32.8\right)$ and $\left(\mathrm{d}, 45.1\right.$ and $39.7,{ }^{2} J_{P P}$ 32.3); $\Lambda_{\mathrm{M}} /\left(\Omega^{-1} \mathrm{~cm}^{2} \mathrm{~mol}^{-1}\right) 32.85$; calcd for $\mathrm{C}_{45} \mathrm{H}_{46} \mathrm{~F}_{6} \mathrm{~N}_{3} \mathrm{O}_{2} \mathrm{P}_{3} \mathrm{SRu}$ : exptl (calc) C, 54.00; H, 4.63; N, 4.20; S, 3.20\%; C, 53.15; H, 4.22; $\mathrm{N}, 4.10 ; \mathrm{S}, 3.15 \%$.

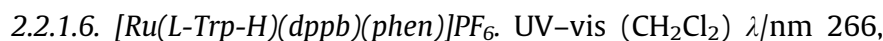
408; IR (CsI) $v / \mathrm{cm}^{-1}$ 3441, 1624, 1385, 854, 557, 509, 426; ${ }^{1} \mathrm{H}$ NMR (400.21 MHz, CDCl $) \delta 1.37\left(\mathrm{~m}, 1 \mathrm{H}, \mathrm{CH}_{2}\right), 2.20-2.00(\mathrm{~m}, 2 \mathrm{H}$, $\left.\mathrm{CH}_{2}\right), 2.54-2.25\left(\mathrm{~m}, 3 \mathrm{H}, \mathrm{CH}_{2}\right), 2.64\left(\mathrm{~m}, 1 \mathrm{H}, \mathrm{CH}_{2}\right), 3.52(\mathrm{~m}, 1 \mathrm{H}$ $\left.\mathrm{CH}_{2}\right), 3.55-3.06(\mathrm{t}, 5 \mathrm{H}, \operatorname{Trp}), 5.99(\mathrm{t}, 2 \mathrm{H}, J 8.8, \mathrm{Ph}), 6.65(\mathrm{t}, 1 \mathrm{H}, J$ $6.8 \mathrm{~Hz}$, phen), 7.57-6.7 (s, 5H, Trp), 7.12 (dt, 1H, J 6.8, 1.6 phen), 7.45-7.35 (m, 4H, Ph), 7.66-7.48 (m, 5H, Ph), 7.82-7.72 (m, 3H, $\mathrm{Ph}), 7.87$ (t, 2H, J 8.0, Ph), 8.05-7.96 (m, 1H, phen; $2 \mathrm{H}, \mathrm{Ph}), 8.14$ (d, $1 \mathrm{H}, J$ 9.2, phen), 8.52-8.49 (m, $1 \mathrm{H}$, phen; $2 \mathrm{H}, \mathrm{Ph}), 8.74(\mathrm{~d}, 1 \mathrm{H}$, $J$ 8.4, phen), $9.20(\mathrm{~d}, 1 \mathrm{H}, J$ 5.2, phen), $9.39(\mathrm{~m}, 1 \mathrm{H}$, phen), $10.96(\mathrm{~s}$, $1 \mathrm{H}, \mathrm{Trp}) ;{ }^{13} \mathrm{C}$ NMR $\left(100.05 \mathrm{MHz}, \mathrm{CDCl}_{3}\right) \delta 27.7,53.4,183.0$ and 181.0; ${ }^{31} \mathrm{P}\left\{{ }^{1} \mathrm{H}\right\}$ NMR $\left(162 \mathrm{MHz}, \mathrm{CH}_{2} \mathrm{Cl}_{2} / \mathrm{D}_{2} \mathrm{O}\right) \delta(\mathrm{d}, 49.4$ and 41.0, $\left.{ }^{2} J_{p p} 34.0\right)$ and (d, 44.8 and 40.7, $\left.{ }^{2} J_{p p} 33.0\right) ; \Lambda_{\mathrm{M}} /\left(\Omega^{-1} \mathrm{~cm}^{2} \mathrm{~mol}^{-1}\right)$ 28.70; calcd for $\mathrm{C}_{51} \mathrm{H}_{47} \mathrm{~F}_{6} \mathrm{~N}_{4} \mathrm{O}_{2} \mathrm{P}_{3} \mathrm{Ru}$ : C, 58.01; H, 4.49; N, 5.31\%; found: $\mathrm{C}, 57.79 ; \mathrm{H}, 4.45 ; \mathrm{N}, 5.47 \%$.

All these spectra are showed in Supplementary information (Figs. S1-S28).

\subsection{Cell culture assay in MDA-MB-231}

The in vitro cytotoxicity assays on cultured human tumor cell lines still represent the standard method for the initial screening of potential anticancer agents. Thus, as a first step in assessing their pharmacological properties, the new ruthenium complexes 
were assayed against a human breast tumor cell line MDA-MB-231 (ATCC No. HTB-26). The cells were routinely maintained in Dulbecco's Modified Eagle's medium (DMEM) supplemented with $10 \%$ fetal bovine serum (FBS), at $37{ }^{\circ} \mathrm{C}$ in a humidified $5 \% \mathrm{CO}_{2}$ atmosphere. After reaching confluence, the cells were detached by trypsinization and counted. For the cytotoxicity assay, $5 \times 10^{4}$ cells were seeded in $200 \mu \mathrm{L}$ of complete medium in 96-well assay microplates (Corning Costar). The plates were incubated at $37^{\circ} \mathrm{C}$ in $5 \% \mathrm{CO}_{2}$ for $24 \mathrm{~h}$ to allow cell adhesion, prior to drug testing. All tested compounds were diluted in sterile DMSO (stock solution with maximum concentration of $20 \mathrm{mmol} \mathrm{L}^{-1}$ ) to $5,2.5,0.2$, and $0.02 \mathrm{mmol} \mathrm{L}^{-1}$. From each of these dilute samples, $2 \mu \mathrm{L}$ aliquots were added to $200 \mu \mathrm{L}$ medium (without FBS) giving a final concentration of DMSO of approximately $1 \%$ and a final concentration of the complex diluted about 100 times. Cells were exposed to the compounds for a $48 \mathrm{~h}$ period. Cell respiration, as an indicator of cell viability, was determined by the mitochondrial-dependent reduction of MTT [3-(4,5-dimethylthiazol-2-yl)-2,5-diphenyltetrazoliumbromide] to formazan [40]. MTT solution $\left(0.5 \mathrm{mg} \mathrm{mL}^{-1}\right)$ was added to cell cultures and incubated for $3 \mathrm{~h}$, after which $100 \mu \mathrm{L}$ of isopropanol were added to dissolve the precipitated formazan crystals. The conversion of MTT to formazan by metabolically viable cells was monitored in an automated microplate reader at $570 \mathrm{~nm}$. The percent cell viability was calculated by dividing the average absorbance of the cells treated with the test compounds by that of the control; and it was plotted against drug concentration (logarithmic scale) to determine the $\mathrm{IC}_{50}$ (drug concentration at which $50 \%$ of the cells are viable relative to the control), with the error estimated from the average of 3 trials.

\subsection{Anti-M. tuberculosis activity assay}

Antimycobacterial activities of each tested compound and the standard drugs cycloserine and ethambutol were determined in triplicate in 96 sterilized flat bottomed micro-plates (Falcon 3072; Becton Dickinson, Lincoln Park, NJ, USA) and Middlebrook 7H9 Broth (Difco) supplemented with oleic acid-albumin-dextrose-catalase (OADC) enrichment (BBL/Becton Dickinson, Sparks, MD, USA). The concentrations of the tested compound ranged from 0.15 to $250 \mu \mathrm{g} \mathrm{mL} \mathrm{m}^{-1}$. The anti-M. tuberculosis activity of the compounds was determined by the REMA (Resazurin Microtiter Assay) method and was used to measure the minimal inhibitory concentration (MIC) for the tested compounds (minimum concentration necessary to inhibit $90 \%$ growth of $M$. tuberculosis $\mathrm{H}_{37} \mathrm{Rv}$ ATCC 27294) [41]. The development of the color pink in the wells was taken as an indicator of bacterial growth and the maintenance of the color blue as the contrary. Thus, the MIC was assumed to be the lowest concentration able to inhibit the change of color from blue to pink. MIC values were determined by fluorescence measured on a SPECTRAfluor Plus microfluorimeter $\left(\right.$ Tecan $^{\circledR}$ ), with excitation at $530 \mathrm{~nm}$ and emission at $590 \mathrm{~nm}$.

\section{Results and discussion}

\subsection{Synthesis of the complexes}

Six complexes of general formula $[\mathrm{Ru}(\mathrm{AA}-\mathrm{H})(\mathrm{dppb})(\mathrm{phen})] \mathrm{PF}_{6}$ (AA-H = deprotonated amino acids; $\mathrm{dppb}=1,4$-bis (diphenylphosphino) butane and phen $=1,10$-phenanthroline) were synthesized and characterized. The elemental analysis data for the synthesized complexes and their molar conductivity measurements $\left(\Lambda_{\mathrm{m}}\right)$, carried out in dichloromethane at $25^{\circ} \mathrm{C}$, using concentrations of $1.0 \times 10^{-3} \mathrm{~mol} \mathrm{~L}^{-1}$ are described in the experimental section. These data are in agreement with the suggested formulation, where the complexes are positively charged.

\subsection{1. ${ }^{31} P\left\{{ }^{1} H\right\},{ }^{13} C\left\{{ }^{1} H\right\}$ and ${ }^{1} H$ NMR studies}

Diastereoisomers were formed for these complexes having chiral amino acids in their structures, which were emphasized by the presence of four doublets in their ${ }^{31} \mathrm{P}\left\{{ }^{1} \mathrm{H}\right\}$ NMR spectra (See Table 1 , Fig. 1B, S12-S16). In this case, the ${ }^{31} \mathrm{P}\left\{{ }^{1} \mathrm{H}\right\}$ NMR spectrum of the complex with glycine, a non-chiral amino acid, exhibits only two doublets (Fig. 1C). This behavior is in agreement with other $\mathrm{Ru}$ (II)/amino acid complexes previously reported by us, and by others $[1,20,35,42]$.

In the ${ }^{13} \mathrm{C}$ NMR spectrum of the complex with glycine (Fig. S6), the $\mathrm{C} 1$ atom of the $\mathrm{COO}^{-}$group is shifted to lower field (183.6 ppm), when compared with the spectrum of metal-free glycine (175.3 ppm). Moreover, the same is observed for the complexes with the chiral amino acids, however in this case all spectra (Figs. S7-S10) show duplication for the signal corresponding the C1 atom, due to the presence of diastereoisomers [1,20,42-44].

\subsubsection{Infrared, UV-visible and electrochemical experiments}

The IR spectra of this series of complexes are very similar for all the complexes (Figs. S17-S22), confirming the presence of the coordinated amino acid ligand in their structures. Thus, deformation bands of the $\mathrm{NH}_{2}$ group, at around $3400 \mathrm{~cm}^{-1}$ and vibrational modes of the carboxylate group occur in the region of $1620 \mathrm{~cm}^{-1}$ for the $v_{\text {ascoo }}$ and at about $1384 \mathrm{~cm}^{-1}$, for the related $v_{\mathrm{scoo}}-$. In the IR spectra of the complexes, the $v_{\mathrm{M}-\mathrm{O}}$ bands at about $509 \mathrm{~cm}^{-1}$, and $v_{\mathrm{M}-\mathrm{N}}$ at about $420 \mathrm{~cm}^{-1}$ were also observed, confirming the coordination of the amino acids by nitrogen and oxygen atoms. In addition, the $\Delta\left(v_{\text {ascoo }}^{-}-v_{\text {scoo }}^{-}\right)$values at about $236 \mathrm{~cm}^{-1}$ confirms that the carboxylates of the amino acids are mono coordinated to the metal center [45].

Concerning the UV-vis experiments, the phenanthroline ligand absorbs in the same region of the dppb and of the amino acids, thus it is difficult to distinguish and assign each transition band in the spectra of the complexes (Table 2, Figs. S23-S28). Therefore, it could be suggested that at about $250 \mathrm{~nm}$, there is a mixture of $\pi \rightarrow \pi^{*}$ bands of these ligands. The band around $400 \mathrm{~nm}$ was assigned as a charge transfer metal-ligand (MLCT) of orbitals $d \pi_{\mathrm{Ru}} \rightarrow 3 \mathrm{p} \sigma^{*} d \pi_{\text {(diphosphine) }}$ and $d \pi_{\mathrm{Ru}} \rightarrow \pi_{(\mathrm{phen}, \text { amino acids) }}^{*}$ [46], which is shifted to higher energies of approximately $20 \mathrm{~nm}$ compared with the starting complex cis-[ $\mathrm{RuCl}_{2}(\mathrm{dppb})($ phen)].

The results of the cyclic voltammetry measurements for the complexes with general formula $[\mathrm{Ru}(\mathrm{AA}-\mathrm{H})(\mathrm{dppb})(\mathrm{phen})] \mathrm{PF}_{6}$ are presented in Table 3, Fig. 2 and S29-S34. The complexes showed a quasi-reversible process, corresponding to an oxidation redox process of one-electron $\left(\mathrm{Ru}^{\mathrm{II}} / \mathrm{Ru}^{\mathrm{III}}\right)$, and another oxidation process belonging to the amino acid ligand [47].

\subsubsection{In vitro antitumor and anti-M. tuberculosis assays}

The MDA-MB-231 tumor cells (human breast carcinoma) were exposed to complexes for a period of $48 \mathrm{~h}$. It is worth mentioning

Table 1

Chemical shifts $(\delta)$ for the ${ }^{31} \mathrm{P}\left\{{ }^{1} \mathrm{H}\right\}$ NMR spectra of $[\mathrm{Ru}(\mathrm{AA}-\mathrm{H})(\mathrm{dppb})(\mathrm{phen})] \mathrm{PF}_{6}$ complexes.

\begin{tabular}{lll}
\hline Complex & $(\delta)$ ppm & ${ }^{2} J_{p-p}(\mathrm{~Hz})$ \\
\hline$[\mathrm{Ru}(\mathrm{Gly}-\mathrm{H})(\mathrm{dppb})(\mathrm{phen})] \mathrm{PF}_{6}$ & 47.2 and 40.7 & 33.4 \\
{$[\mathrm{Ru}(\mathrm{L}-\mathrm{Ala}-\mathrm{H})(\mathrm{dppb})(\mathrm{phen})] \mathrm{PF}_{6}$} & 46.9 and 38.4 & 33.2 \\
& 44.7 and 38.1 & 33.2 \\
{$[\mathrm{Ru}(\mathrm{L}-\mathrm{Val}-\mathrm{H})(\mathrm{dppb})($ phen $)] \mathrm{PF}_{6}$} & 47.0 and 38.9 & 33.0 \\
& 42.9 and 38.5 & 32.8 \\
{$[\mathrm{Ru}(\mathrm{L}-\mathrm{Tyr}-\mathrm{H})(\mathrm{dppb})(\mathrm{phen})] \mathrm{PF}_{6}$} & 47.8 and 38.9 & 34.4 \\
& 42.9 and 38.1 & 32.9 \\
{$[\mathrm{Ru}(\mathrm{L}-\mathrm{Met}-\mathrm{H})(\mathrm{dppb})(\mathrm{phen})] \mathrm{PF}_{6}$} & 48.0 and 40.1 & 32.8 \\
& 45.1 and 39.7 & 32.3 \\
{$[\mathrm{Ru}(\mathrm{L}-\mathrm{Trp}-\mathrm{H})(\mathrm{dppb})(\mathrm{phen})] \mathrm{PF}_{6}$} & 49.4 and 41.0 & 34.0 \\
& 44.8 and 40.7 & 33.0 \\
\hline
\end{tabular}




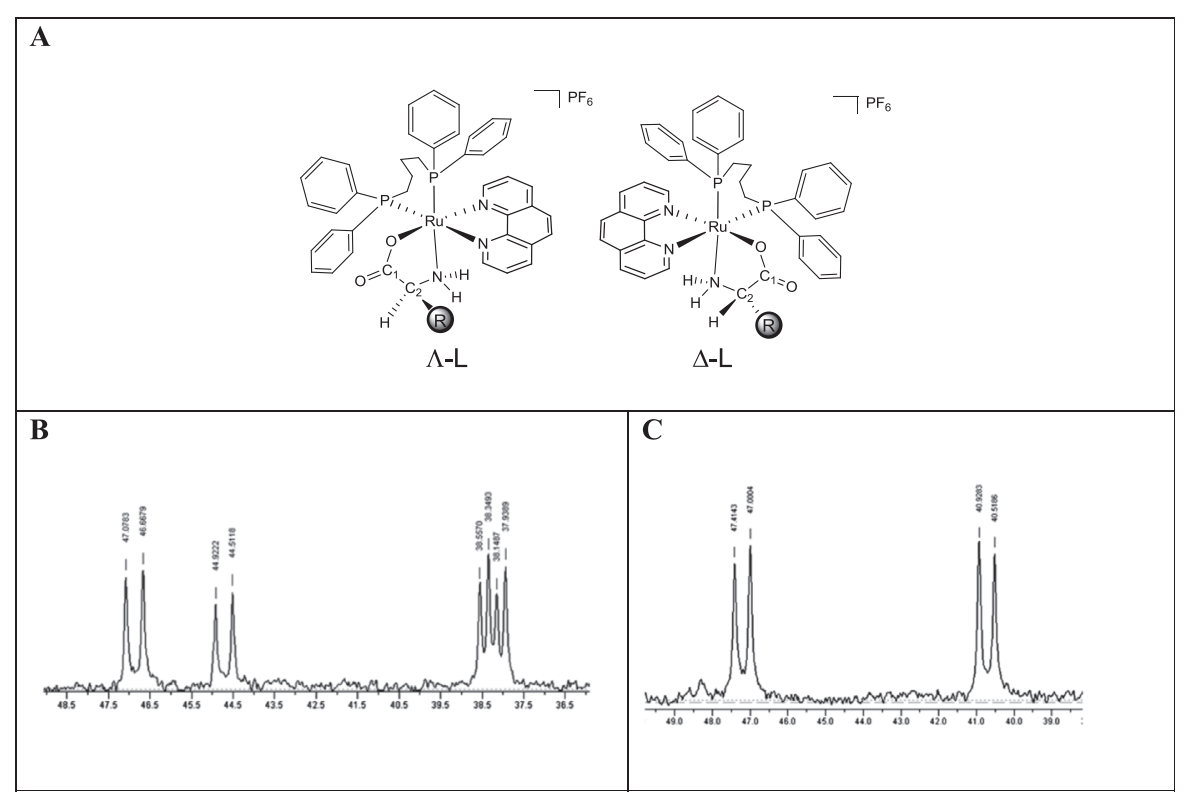

Fig. 1. Diastereoisomers structures $(A) \cdot{ }^{31} \mathrm{P}\left\{{ }^{1} \mathrm{H}\right\}$ NMR spectra for the complexes: $(\mathrm{B})[\mathrm{Ru}(\mathrm{L}-\mathrm{Ala}-\mathrm{H})(\mathrm{dppb})(\mathrm{phen})] \mathrm{PF}$ and $(\mathrm{C})[\mathrm{Ru}(\mathrm{Gly}-\mathrm{H})(\mathrm{dppb})(\mathrm{phen})] \mathrm{PF}$.

Table 2

Data of the UV-vis spectra of the complexes $[\mathrm{Ru}(\mathrm{AA}-\mathrm{H})(\mathrm{dppb})(\mathrm{phen})] \mathrm{PF}_{6}$, in $\mathrm{CH}_{2} \mathrm{Cl}_{2}$ solutions $\left[5.0 \times 10^{-5} \mathrm{~L} \mathrm{~mol}^{-1}\right]$.

\begin{tabular}{|c|c|c|c|}
\hline Complex & $\lambda(\mathrm{nm})$ & $\begin{array}{l}(\varepsilon) \text { Molar } \\
\text { absorptivity } \\
\mathrm{L} \mathrm{mol}^{-1} \mathrm{~cm}^{-1}\end{array}$ & Transition \\
\hline \multirow[t]{3}{*}[\mathrm{Ru}(\mathrm{Gly}-\mathrm{H})(\mathrm{dppb})(\mathrm{phen})]{$\mathrm{PF}_{6}$} & 266 & 26460 & $\pi \rightarrow \pi^{*}$ \\
\hline & $294(\mathrm{sh})$ & - & - \\
\hline & 374 & 3494 & $d \pi \rightarrow \pi^{*}$ \\
\hline \multirow[t]{3}{*}[\mathrm{Ru}(\mathrm{L}-\mathrm{Ala}-\mathrm{H})(\mathrm{dppb})(\mathrm{phen})]{$\mathrm{PF}_{6}$} & 270 & 28354 & $\pi \rightarrow \pi^{*}$ \\
\hline & $290(\mathrm{sh})$ & - & - \\
\hline & 408 & 4616 & $d \pi \rightarrow \pi^{*}$ \\
\hline \multirow{3}{*}[\mathrm{Ru}(\mathrm{L}-\mathrm{Val}-\mathrm{H})(\mathrm{dppb})(\mathrm{phen})]{$\mathrm{PF}_{6}$} & 270 & 30833 & $\pi \rightarrow \pi^{*}$ \\
\hline & $292(\mathrm{sh})$ & - & - \\
\hline & 408 & 4870 & $d \pi \rightarrow \pi^{*}$ \\
\hline \multirow{3}{*}[\mathrm{Ru}(\mathrm{L}-\mathrm{Tyr}-\mathrm{H})(\mathrm{dppb})(\mathrm{phen})]{$\mathrm{PF}_{6}$} & 270 & 31626 & $\pi \rightarrow \pi^{*}$ \\
\hline & $292(\mathrm{sh})$ & - & - \\
\hline & 408 & 4891 & $d \pi \rightarrow \pi^{*}$ \\
\hline \multirow{3}{*}[\mathrm{Ru}(\mathrm{L}-\mathrm{Met}-\mathrm{H})(\mathrm{dppb})(\mathrm{phen})]{$\mathrm{PF}_{6}$} & 270 & 30911 & $\pi \rightarrow \pi^{*}$ \\
\hline & $292(\mathrm{sh})$ & - & - \\
\hline & 406 & 4666 & $d \pi \rightarrow \pi^{*}$ \\
\hline \multirow{3}{*}[\mathrm{Ru}(\mathrm{L}-\mathrm{Trp}-\mathrm{H})(\mathrm{dppb})(\mathrm{phen})]{$\mathrm{PF}_{6}$} & 270 & 30251 & $\pi \rightarrow \pi^{*}$ \\
\hline & $290(\mathrm{sh})$ & - & - \\
\hline & 408 & 4330 & $d \pi \rightarrow \pi^{*}$ \\
\hline
\end{tabular}

sh = sholder.

Table 3

Cyclic Voltammetry data (mV) for complexes [Ru(AA-H)(dppb)(phen)]PF $\mathrm{Pin}_{6} \mathrm{CH}_{2} \mathrm{Cl}_{2}$, $0.1 \mathrm{~mol} \mathrm{~L}^{-1} \mathrm{PTBA}, 100 \mathrm{mV} \mathrm{s}^{-1}$. Work and auxiliary electrodes of $\mathrm{Pt}$, and $\mathrm{Ag} / \mathrm{AgCl}$ as a reference electrode.

\begin{tabular}{lllll}
\hline Complex & $\begin{array}{l}\mathrm{Ru}^{\mathrm{II}} / \mathrm{Ru}^{\mathrm{III}} \\
\left(\mathrm{E}_{\mathrm{pa}}\right)\end{array}$ & $\begin{array}{l}\mathrm{Ru}^{\mathrm{III}} / \mathrm{Ru}^{\mathrm{II}} \\
\left(\mathrm{E}_{\mathrm{pc}}\right)\end{array}$ & $\mathrm{E}_{1 / 2}$ & $\mathrm{i}_{\mathrm{pa}} / \mathrm{i}_{\mathrm{pc}}$ \\
\hline$[\mathrm{Ru}(\mathrm{Gly}-\mathrm{H})(\mathrm{dppb})(\mathrm{phen})] \mathrm{PF}_{6}$ & 1112 & 1027 & 1069 & 1.40 \\
{$[\mathrm{Ru}(\mathrm{L}-\mathrm{Ala}-\mathrm{H})(\mathrm{dppb})(\mathrm{phen})] \mathrm{PF}_{6}$} & 1075 & 999 & 1044 & 0.90 \\
{$[\mathrm{Ru}(\mathrm{L}-\mathrm{Val}-\mathrm{H})(\mathrm{dppb})(\mathrm{phen})] \mathrm{PF}_{6}$} & 1079 & 979 & 1029 & 0.98 \\
{$[\mathrm{Ru}(\mathrm{L}-\mathrm{Tyr}-\mathrm{H})(\mathrm{dppb})(\mathrm{phen})] \mathrm{PF}_{6}$} & 1096 & - & - & - \\
{$[\mathrm{Ru}(\mathrm{L}-M e t-H)(\mathrm{dppb})($ phen$)] \mathrm{PF}_{6}$} & 1113 & 1003 & 1058 & 0.95 \\
{$[\mathrm{Ru}(\mathrm{L}-\mathrm{Trp}-\mathrm{H})(\mathrm{dppb})(\mathrm{phen})] \mathrm{PF}_{6}$} & 1053 & - & - & - \\
\hline
\end{tabular}

that the complexes are stable in the conditions of the in vitro studies (1\% DMSO + DMEM, supplemented with $10 \%$ fetal bovine serum), for at least five days, as showed ${ }^{31} \mathrm{P}\left\{{ }^{1} \mathrm{H}\right\}$ NMR experiments. In this case the ${ }^{31} \mathrm{P}\left\{{ }^{1} \mathrm{H}\right\}$ NMR data of the complexes of fresh

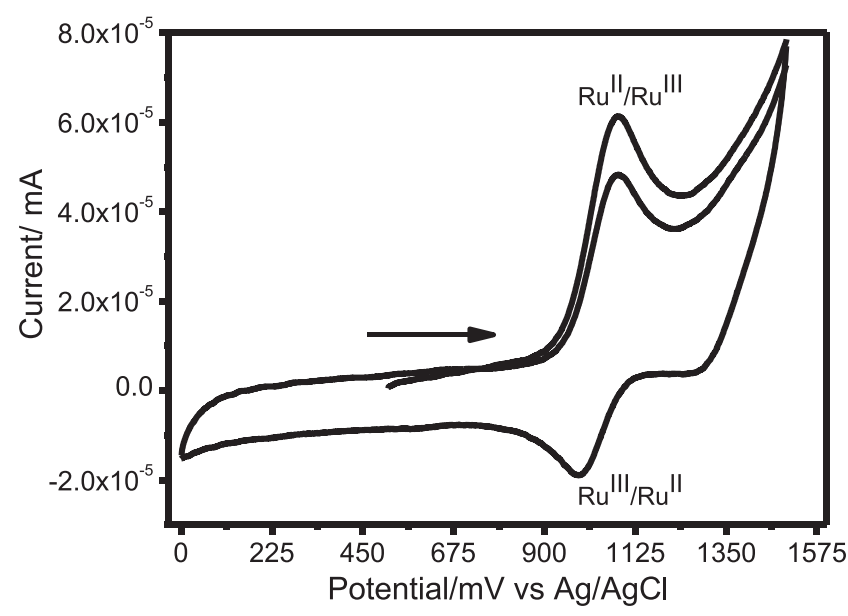

Fig. 2. The Cyclic voltammogram of the $[\mathrm{Ru}(\mathrm{L}-\mathrm{Val}-\mathrm{H})(\mathrm{dppb})(\mathrm{phen})] \mathrm{PF}_{6}$ complex: TBAP $0.1 \mathrm{~mol} \mathrm{~L}^{-1} ; \mathrm{CH}_{2} \mathrm{Cl}_{2} ; \mathrm{Ag} / \mathrm{AgCl}$; scan rate of $100 \mathrm{mV} \mathrm{s}^{-1}$.

\section{Table 4}

$\mathrm{IC}_{50}$ values for the MDA-MB-231 cell line and MIC values for the M. tuberculosis of the $[\mathrm{Ru}(\mathrm{AA}-\mathrm{H})(\mathrm{dppb})(\mathrm{phen})] \mathrm{PF}_{6}$ complexes, the ligands and the reference drugs.

\begin{tabular}{|c|c|c|}
\hline Complex & $\left.\mathrm{IC}_{50}(\mu \mathrm{mol} \mathrm{L})^{-1}\right)$ & $\operatorname{MIC}\left(\mu \mathrm{g} \mathrm{mL}^{-1}\right)$ \\
\hline$[\mathrm{Ru}(\mathrm{Gly}-\mathrm{H})(\mathrm{dppb})(\mathrm{phen})] \mathrm{PF}_{6}$ & $4.17 \pm 0.16$ & 1.53 \\
\hline $\mathrm{Ru}(\mathrm{L}-\mathrm{Ala}-\mathrm{H})(\mathrm{dppb})(\mathrm{phen})] \mathrm{PF}_{6}$ & $6.68 \pm 0.02$ & 1.56 \\
\hline$[\mathrm{Ru}(\mathrm{L}-\mathrm{Val}-\mathrm{H})(\mathrm{dppb})(\mathrm{phen})] \mathrm{PF}_{6}$ & $7.44 \pm 0.86$ & 1.51 \\
\hline$[\mathrm{Ru}(\mathrm{L}-\mathrm{Tyr}-\mathrm{H})(\mathrm{dppb})(\mathrm{phen})] \mathrm{PF}_{6}$ & $3.04 \pm 0.60$ & 1.59 \\
\hline$[\mathrm{Ru}(\mathrm{L}-\mathrm{Met}-\mathrm{H})(\mathrm{dppb})($ phen $)] \mathrm{PF}_{6}$ & $5.84 \pm 0.28$ & 3.10 \\
\hline$[\mathrm{Ru}(\mathrm{L}-\mathrm{Trp}-\mathrm{H})(\mathrm{dppb})(\mathrm{phen})] \mathrm{PF}_{6}$ & $4.72 \pm 0.07$ & 0.78 \\
\hline cis- $\left[\mathrm{RuCl}_{2}(\mathrm{dppb})(\mathrm{phen})\right]$ & $23.86 \pm 0.65$ & 7.80 \\
\hline cis- $\left[\mathrm{PtCl}_{2}\left(\mathrm{NH}_{3}\right)_{2}\right]$ & $2.44 \pm 0.24$ & - \\
\hline Amino acids & $>200$ & $>25$ \\
\hline dppb & $>200$ & $>25$ \\
\hline phen & $>200$ & $>25$ \\
\hline Cycloserine & - & $12.5-50.0$ \\
\hline Ethambutol & 1.02 & 5.62 \\
\hline
\end{tabular}

solutions and after 5 days were the same, and comparable with those one obtained in $\mathrm{CH}_{2} \mathrm{Cl}_{2}$ solutions. The $\mathrm{IC}_{50}$ (drug concentration at which $50 \%$ of the cells are viable relative to the control) 


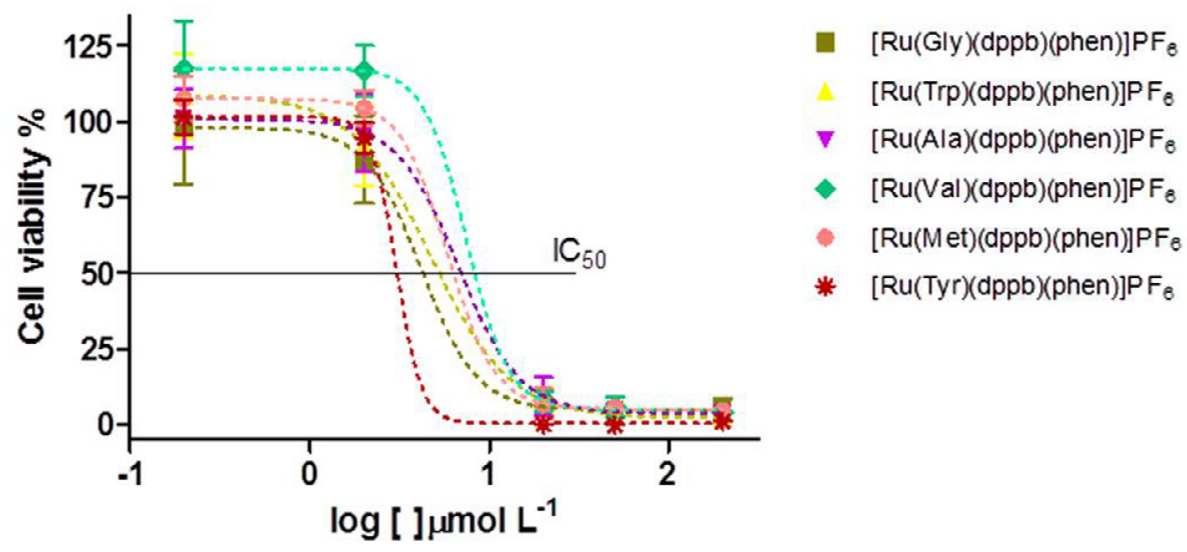

Fig. 3. Graph of cell viability against MDA-MB-231 breast cancer cell lines for the series of complexes [Ru(AA-H)(dppb)(phen)]PF , $\mathrm{MTT}$ assays.

values, calculated from the dose-survival curves as shown in Fig. 3 and Table 4. For comparison purposes, the cytotoxicity of cisplatin was also evaluated under the same experimental conditions.

The complexes with amino acids are all positively charged compounds, whereas the precursor, cis-[ $\left.\mathrm{RuCl}_{2}(\mathrm{dppb})(\mathrm{phen})\right]$, is neutral. This may be one of the factors contributing to the lower $\mathrm{IC}_{50}$ values for the complexes with amino acids. Indeed, the $\mathrm{IC}_{50}$ values of the complexes with amino acids are similar, with values in the range of 3.04-7.44 $\mu \mathrm{mol} \mathrm{L}^{-1}$ (Table 4). This indicates that structural variation of the amino acid ligands does not affect the cytotoxicity of the compounds; activity of the amino acid complexes could be similarity to those reported in the literature [30,48-49] and studies performed by our research group [1], revealed weak interaction between the complexes and DNA. Therefore, these results allow us to suggest that the complexes studied in this work also present weak interaction with DNA [50].

Comparing the cytotoxicity results obtained for $[\mathrm{Ru}(\mathrm{AA}-\mathrm{H})$ $(\mathrm{dppb})($ phen) $] \mathrm{PF}_{6}$ complexes with the $\mathrm{IC}_{50}$ values of analogous complexes, it can be observed that the complexes reported here present more active, when compared with complexes with $2,2^{\prime}$ bipyridine, with formulae $[\mathrm{Ru}(\mathrm{AA}-\mathrm{H})(\mathrm{dppb})(\mathrm{bipy})] \mathrm{PF}_{6}$ $\left(\mathrm{IC}_{50}=5.0 \pm 1.5\right.$ to $28.5 \pm 5.2 \mu \mathrm{mol} \mathrm{L}^{-1}$ ) [1], suggesting the importance of the planarity e rigidity of the phenanthroline ligand, to increase the biological activity of the complexes here studied.

The in vitro anti-M. tuberculosis properties of the complexes with amino acids were evaluated against $M$. tuberculosis $\mathrm{H}_{37} \mathrm{Rv}$ ATCC 27294. The MIC values of the complexes summarized here are presented in Table 4 . These values are comparable to ethambutol (MIC $5.61 \mu \mathrm{g} \mathrm{mL}^{-1}$ ) and cycloserine (MIC 12.5-50.0 $\mu \mathrm{g} \mathrm{mL}^{-1}$ ), which are first-line and second-line drugs, respectively $[51,52]$. These results confirm the anti-Mycobacterium tuberculosis activities of the $[\mathrm{Ru}(\mathrm{AA}-\mathrm{H})(\mathrm{dppb})(\mathrm{phen})] \mathrm{PF}_{6}$ complexes. Furthermore, the MIC results show that complexation of amino acids improved activity of the complexes compared with the precursor cis- $\left[\mathrm{RuCl}_{2}(-\right.$ dppb)(phen)].

The biphosphinic ligand (1, 4-bis-(diphenylphosphino)butane) is slightly active against the Mycobacterium tuberculosis ( $\mathrm{MIC}>50 \mu \mathrm{g} \mathrm{mL}^{-1}$ ) [39]. Therefore, when this molecule is coordinated to the ruthenium, the inhibitory activity of the new species is improved greatly as shown by the data presented in Table 4.

\section{Conclusion}

Six new ruthenium complexes with general formulae [Ru(AA$\mathrm{H})(\mathrm{dppb})(\mathrm{phen})] \mathrm{PF}_{6}$ were synthesized, characterized and their biological activity was evaluated, against MDA-MB-231 tumor cells and as anti-Mycobacterium tuberculosis.
The ${ }^{31} \mathrm{P}\left\{{ }^{1} \mathrm{H}\right\}$ NMR data show the presence of diastereoisomers for those complexes containing amino acid ligand, which have chiral carbon in their structures. The $\mathrm{IC}_{50}$ values for the MDA-MB-231 tumor cells obtained for $\mathrm{Ru}(\mathrm{II})$ complexes showed better activity than the cisplatin (reference drug). The anti-Mycobacterium tuberculosis activity assays for the new complexes provided evidence that the complexes show higher activity against $M$. tuberculosis H37Rv, than the ethambutol, a first-line drug in several schemes of conventional tuberculosis treatment, and also higher than the cycloserine, a second-line drug used in the tuberculosis treatment.

Thus, these good biological results suggest that the title complexes are potential metallodrugs to be used against the MDAMB-231 tumor cells and anti-mycobacterium tuberculosis.

\section{Acknowledgements}

We would like to thank CNPq, CAPES and FAPESP for the financial support.

\section{Appendix A. Supplementary data}

Supplementary data associated with this article can be found, in the online version, at http://dx.doi.org/10.1016/j.ica.2017.04.012.

\section{References}

[1] M.A.P. Almeida, F.B. Nascimento, A.E. Graminha, A.G. Ferreira, J. Ellena, F.M.S. Mello, A.P. Lima, E.P. Silveira-Lacerda, A.A. Batista, Polyhedron 81 (2014) 735

[2] M.I.F. Barbosa, R.S. Corrêa, L.V. Pozzi, É.O. Lopes, F.R. Pavan, C.Q.F. Leite, J. Ellena, S.P. Machado, G. Von Poelhsitz, A.A. Batista, Polyhedron 85 (2015) 376.

[3] P. Bergamini, V. Ferretti, P. Formaglio, A. Marchi, L. Marvelli, F. Sforza, Polyhedron 78 (2014) 54.

[4] S. Betanzos-Lara, N.P. Chmel, M.T. Zimmerman, L.R. Barrón-Sosa, C. Garino, L. Salassa, A. Rodger, J.L. Brumaghim, I. Gracia-Mora, N. Barba-Behrens, Dalton Trans. 44 (2015) 3673.

[5] I.P. Ejidike, P.A. Ajibade, Bioinorg. Chem. Appl. (2015) 1.

[6] I.H. Hall, C.B. Lackey, T.D. Kistler, R.W. Jr Durham, E.M. Jouad, M. Khan, X.D. Thanh, S. Djebbar-Sid, O. Benali-Baitich, G.M. Bouet, Pharmazie 55 (2000) 937.

[7] P. Kalaivani, R. Prabhakaran, E. Vaishnavi, T. Rueffer, H. Lang, P. Poornima, R. Renganathan, V.V. Padmad, K. Natarajan, Inorg. Chem. Front. 1 (2014) 311.

[8] P. KoÈpf-Maier, H. Koepf, Chem. Rev. 87 (1987) 1137.

[9] V.X. Jin, J.D. Ranford, Chim. Acta. 304 (2000) 38.

[10] X.J. Luo, Q.P. Qin, Y.L. Li, Y.C. Liu, H. Liang, Indian J. Chem. 53 (2014) 787.

[11] D.L. Ma, C.M. Che, F.M. Siu, M. Yang, K.Y. Wong, Inorg. Chem. 46 (2007) 740.

[12] S. Maddila, S. Gorle, N. Seshadri, P. Lavanya, S.B. Jonnalagadd, Arab. J. Chem. 9 (2016) 681.

[13] G. Mestroni, E. Alessio, G. Sava, S. Pacor, M. Coluccia, A. Boccarelli, 1 (1994) 41.

[14] S. Mokesch, M.S. Novak, A. Roller, M.A. Jakupec, W. Kandioller, B.K. Keppler, Organometallics 34 (2015) 848.

[15] M.A. Mondelli, A.E. Graminha, R.S. Corrêa, M.M. Silva, A.P. Carnizello, G. Von Poelhsitz, J. Ellena, V.M. Deflon, G.F. Caramori, M.H. Torre, D.C. Tavares, A.A. Batista, Polyhedron 68 (2014) 312.

[16] N.R. Palepu, J.R. Premkumar, A.K. Verma, K. Bhattacharjee, S.R. Joshi, S. Forbes, Y. Mozharivskyj, K.M. Rao, doi: http://dx.doi.org/10.1016/j.arabjc.2015.10.011. 
[17] H.K.P. Porto, C.A.S.T. Vilanova-Costa, F.M.S. Mello, W.L. Costa, A.P. Lima, F.C. Pereira, M.A.P. Almeida, A.E. Graminha, A.A. Batista, E.P. Silveira-Lacerda, Transition Met. Chem. 40 (2015) 1.

[18] A. Rathgeb, A. Böhm, M.S. Novak, A. Gavriluta, O. Dömötör, J.B. Tommasino, E.A. Enyedy, S. Shova, S. Meier, M.A. Jakupec, D. Luneau, V.B. Arion, Inorg. Chem. 53 (2014) 2718.

[19] E.R. dos Santos, M.A. Mondelli, L.V. Pozzi, R.S. Corrêa, H.S. Salistre-de-Araújo, F. R. Pavan, C.Q.F. Leite, J. Ellena, V.R.S. Malta, S.P. Machado, A.A. Batista, Polyhedron 51 (2013) 292.

[20] E.R. Santos, R.S. Corrêa, J.U. Ribeiro, A.E. Graminha, J. Ellena, H.S. Selistre-deAraujo, A.A. Batista, J. Coord. Chem. 69 (2016) 3518

[21] A.R. Souza, R. Najjar, S. Glikmanas, S.B. Zyngier, J. Inorg. Biochem. 64 (1996) 1.

[22] C.S. Allardyce, P.J. Dyson, Platin. Met. Rev. 45 (2001) 62.

[23] V. Brabec, O. Nováková, Drug Resist. Update 9 (2006) 111.

[24] M.J. Clarke, Coord. Chem. Ver. 232 (2002) 69.

[25] I. Kostova, Curr. Med. Chem. 13 (2006) 1085

[26] J.C.S. Lopes, J.L. Damasceno, P.F. Oliveira, A.P.M. Guedes, D.C. Tavares, V.M. Deflon, N.P. Lopes, M. Pivatto, A.A. Batista, P.I.S. Maiag, G.V. Poelhsitz, J. Braz. Chem. Soc. 26 (2015) 1838.

[27] S.J. Lau, B. Sarkar, J. Biol. Chem. 246 (1971) 5938.

[28] K. Majumder, S. Bhattacharya, Polyhedron 18 (1999) 3669.

[29] S.M. Masoud, M.F. Amira, M.R. Ramadan, G.M. El-Ashry, Spectrochim. Acta A 69 (2008) 230.

[30] Y. Nakabayashi, Y. Watanabe, T. Nakao, O. Yamauchi, Inorg. Chim. Acta 357 (2004) 2553.

[31] J.R. Aldrich-Wright, R.S. Vagg, P.A. Williams, Coord. Chem. Rev. 166 (1997) 361.

[32] J.R. Aldrich-Wright, R.S. Vagg, P.A. Williams, Aust. J. Chem. 56 (2003) 1193.

[33] S. Robert, A.W. Peter, Inorg. Chim. Acta 52 (1981) 69.
34] F.S. Stephens, S. Robert, A.W. Peter, Inorg. Chim. Acta 72 (1983) 253.

35] W.S. Sheldrick, R. Exner, Inorg. Chim. Acta 175 (1990) 261.

[36] W. Sheldrick, R. Exner, Inorg. Chim. Acta 184 (1991) 119.

37] J.G. Terence, A.W. Peter, R.S. Vagg, Inorg. Chim. Acta 63 (1982) 133.

38] B.A.V. Lima, R.S. Corrêa, A.E. Graminha, A. Kuznetsov, J. Ellena, F.R. Pavan, C.Q.F. Leite, A.A. Batista, J. Braz. Chem. Soc. 27 (2016) 30.

[39] F.B. Nascimento, G. Von Poelhsitz, F.R. Pavan, D.N. Sato, C. Leite, H.S. Elistre-deAraújo, J. Ellena, E.E. Castellano, V.M. Deflon, A.A. Batista, J. Inorg. Biochem. 102 (2008) 1783.

[40] T. Mosmann, J. Immunol. Methods 65 (1983) 55.

[41] J.C. Palomino, A. Martin, M. Camacho, H. Guerra, J. Swings, F. Portaela, Antimicrob. Agents Chemother. 46 (2002) 2720.

[42] S. Shinoda, N. Inoue, T. Keiji, Y. Saito, Inorg. Chim. Acta 65 (1982) L21.

[43] P.P. Corbi, F. Cagnin, L.P.B. Sabeh, A.C. Massabni, C.M. Costa-Neto, Spectrochim. Acta A 66 (2007) 1171.

[44] H. Xu, L. Chen, Spectrochim. Acta A 59 (2003) 657.

[45] K. Nakamoto, Infrared and Raman of Inorganic and Coordination Compounds, 5th ed., Wiley-Interscience, New York, EUA, 1997.

[46] A.B.P. Lever, Inorganic Electronic Spectroscopy, 2th ed., Elsevier, Amsterdam, 1984.

[47] K. Ogura, M. Kobayashi, M. Nakayama, Y. Miho, J. Electroanal. Chem. 449 (1998) 101.

[48] H. Chao, W.J. Mei, Q.W. Huang, L.N. Ji, J. Inorg. Biochem. 92 (2002) 165.

[49] M.S. Deshpande, A.S. Kumbhar, J. Chem. Sci. 117 (2005) 153.

[50] J.-Q. Wang, Z.-Z. Zhao, H.-B. Bo, Q.-Z. Chen, J. Coord. Chem. 69 (2016).

51] M. Protopopova, C. Hanrahan, B. Nikonenko, R. Samala, P. Chen, J. Gearhart, L. Einck, C.A. Nacy, J. Antimicrob. Chemother. 56 (2005) 968.

[52] R.P. Tripathi, N. Tewari, N. Dwivedi, V.K. Tiwari, Med. Res. Rev. 25 (2005) 93. 